\title{
What's happening in Taranaki? Social workers and the environment
}

Lesley Pitt

Lesley Pitt is a social work tutor at the Western Institute of Technology at Taranaki, based in New Plymouth.

\section{Abstract}

Climate change is altering our physical world (Alston 2013; Gray, Coates \& Hetherington 2013; Dominelli 2012; Hetherington \& Boddy 2013; Intergovernmental Panel on Climate Change [IPCC] 2012) and forcing us to consider the way we live with Papa-tūâ-nuku. Globally, nationally and locally we are forced to consider 'green' issues as a result of climate change (Alston 2013; Coates 2004; Coates 2003; Gray, Coates \& Hetherington 2013; IPCC 2012). The International Federation of Social Workers (2013:4) state, ' ...the last twenty years has demonstrated as never before the inter-dependence of life on the globe', and advocate for social workers recognising the importance of the natural world in their work. This article considers what this means for social workers in Taranaki.

\section{Introduction}

In the latest edition of Social Work: Contexts and Practice, Margaret Alston (2013: 31) identifies, '...the environment as an emerging field of practice'. She comments that for a profession based on person in environment, social work has focused its gaze on the social environment, turning a 'blind eye' to the physical world. Coates (2003) refers to the social work profession as anthropocentric, that is, considering nature as a resource to be used for the benefit of humans rather than seeing the human and non-human worlds as an integrated whole.

The idea that social work as a profession should attend to the physical world of clients as well as the social world is part of a global body of literature where social work and its need to address environmental issues is discussed (Alston 2013; Besthorn 2013; Coates 2004; Coates 2003; Dewane 2011; Gray, Coates \& Hetherington 2013). The global agenda for social work and social development: Commitment to action (2012) identifies that climate change is resulting in inequalities and unsustainable environments, consequently their priority focus during the period 2012-2015 is environmental sustainability (International Federation of Social Workers, International Association of Schools of Social Work \& International Council on Social Welfare 2012). Internationally, social workers are advocating for environmental justice alongside social justice (Alston 2013, Besthorn 2011; Coates 2011, Coates 2004; Coates 2003; Dewane 2011; Dominelli 2012, International Federation of Social Workers, International Association of Schools of Social Work \& International Council on Social Welfare 2012; Zapf 2010), arguing they should be addressed together. 
However, a literature search in relation to Aotearoa New Zealand produced little in the way of material about the environment and social work practice. This is not to say people are not interested or concerned about environmental issues, but we have yet to build a body of literature. This small project has been carried out in the hope it will encourage debate and further research. It documents the experiences of some practitioners in Taranaki by asking what social work and its connection to the natural world means to them.

Reflecting on the environment and social work in Taranaki, I wondered if in an area economically dependent on two industries which are identified as environmentally, or potentially environmentally, damaging, as in the case of hydraulic fracturing and deep sea oil and gas exploration (Climate Justice Taranaki 2012; Greenpeace 2012), that social work practitioners would feel a tension between the needs of clients to have employment, particularly well paid work as in the case in the oil industry, and the needs of environmental safety, sustainability and justice. I wanted to explore this idea and was interested in how practitioners experienced this. Taranaki relies economically on the dairy and oil and gas industries (Venture Taranaki 2013), but these industries have an environmental and social cost (Climate Justice Taranaki 2012; Greenpeace 2012). Deep sea exploration by Anadarko off the west coast of the North Island makes this a pressing reality.

In order to explore this, and to gain an understanding of how local social workers saw the place of the environment in their work, a series of qualitative interviews were carried out. The research question was: to what degree, and how, do social workers in Taranaki connect their day-to-day practice with the natural environment? This small, exploratory project relied on willing participants who were purposefully chosen (Sarantakos 2013). It does not necessarily represent all Taranaki social workers, but does include a range of 'voices'. It is hoped that this will inspire discussion and more comprehensive and rigorous research.

From the research there are examples of social work practice which is deeply connected to the land and engaged with the environment as well as the 'social'. The themes fall into six areas which are, firstly, concern over clients' disconnection from the environment, secondly, practitioners using the environment in order to build relationships and thirdly, a theme of making connections for clients to the physical world to enhance healing. The fourth theme was gardening and using this as a tool or 'vehicle' in which to address poverty. More closely aligned with what Dominelli (2012) refers to as 'green' social work was the fifth theme of challenging the impact of capitalism and, lastly, practitioners identified and described the difference between poor and affluent clients.

From the literature there are different ideas and ways of talking about social work and the environment. Besthorn (2011), Coates (2011) and Zapf (2006) talk about deep ecology which derives from eco-systems theory. Gray, Coates and Hetherington (2013), in writing from an ecological perspective, discuss the need for a paradigm shift among social work practitioners to develop their ecological consciousness. This is the idea that the person-in-environment approach needs to expand to incorporate the natural as well as social environment (Alston 2013; Besthorn 2011; Coates 2004; Coates 2003; Gray, Coates \& Hetherington 2013; Zapf 2006). Coates (2003) argues that social workers can 'speak to' the impact of environmental damage on the wellbeing of communities and can support people to reconnect with the physical world. Taranaki has a rich natural world for people to connect to, albeit one which has been damaged, and is at risk from, the oil and gas and dairy industries. 
A critical theory perspective underpins the idea of 'green' social work discussed by Dominelli (2012). In defining 'green' social work she states it is more political than ecological social work and it questions structural inequalities and the unequal distribution of resources (Dominelli 2012). Literature from an ecological framework would dispute her view that their perspective is not political, stating they believe in a need for political action for environmental justice. This is espoused by Coates (2003) when he says that, '...ecological devastation and social injustice result from the same processes and belief systems' (p. 6). He critiques global capitalism for its focus on competition, rationalism and individualism which result in the demise of people's connection to the environment and each other.

The wider context we live in is one in which there is climate change as a result of excessive greenhouse gas in the atmosphere, which results in global warming (Alston 2013; Coates 2003; International Bank for Reconstruction and Development/World Bank 2012; IPCC 2012). Recent droughts in Aotearoa New Zealand and in Australia and the recent bush fires in New South Wales are evidence of climate change. The IPCC (2007) identified extreme weather events in Aotearoa New Zealand as floods and droughts. The International Bank for Reconstruction and Development/ World Bank (2012) report on global warming identifies that if changes are not made, '... a warming of 4 degrees $C$ could occur as early as the 2060s' (p. xiii). This would lead to an estimated sea level rise of 0.5-1 metre, and this will result in heat waves, floods, severe droughts and an increase in tropical cyclones (International Bank for Reconstruction and Development/World Bank 2012).

\section{Environmental issues in Taranaki}

In Taranaki, the impact of droughts on the farming community has already been felt, with the 2011 drought affecting dairy farmers in south Taranaki. The dairy industry, known as producing 'white gold', is economically significant to the province and has a significant role in providing employment, both on farms and in factories such as Fonterra's plant in Hawera. However, there is an environmental cost. In relation to the dairy industry in Aotearoa New Zealand, Greenpeace (2012) has identified that it is, '...responsible for the entire increase in greenhouse gas emissions from the agricultural sector since 1990' (para. 1). Dairying practices release greenhouse gases, methane and nitrous oxide, and historically have discharged effluent into waterways. In 1981 a claim was made by the Te Atiawa people to the Waitangi Tribunal about the, '.... discharge of sewage and industrial waste into the sea between New Plymouth and Waitara' (Waitangi Tribunal 1983: para. 1) and the claim was upheld by the tribunal.

The other 'big player' in the province economically is the oil and gas industry, producing 'black gold'; the area is known as the 'energy province' of New Zealand (Venture Taranaki 2013). The majority of oil and gas produced in New Zealand comes from Taranaki and the industry is perceived to be an important employer, known to the 'locals' as an industry which 'pays well'. The environmental impact of the oil and gas industry is disturbing and the long-term damage from having the industry in the province is unknown, with impending risks from deep sea oil exploration off the west coast of the North Island. The practice of hydraulic fracturing (fracking) continues despite the environmental unknowns (Climate Justice Taranaki 2012). Greenpeace (2012) says hydraulic fracturing is associated with poisoned water, air pollution, health risks and an increased potential for earthquakes. There are 'burn offs' of gas and oil from wells which affects air quality and the lives of those who live 
nearby. Part of what inspired this research was my interest in the tension between the need for employment and a strong economy for clients versus the environmental damage and / or risk. This was not discussed directly by respondents, their focus was on clients' day-to-day reality and looking for solutions to issues presented to them in their practice. There was discussion about poor housing of rural clients, some of whom are employed in dairying. As your landlord is often also your employer it is difficult to advocate for improvements.

\section{Research process}

I began this qualitative project by inviting members of ANZASW in Taranaki to participate. There was one response to this, so I then contacted practitioners known to have an interest in environmental issues. In research terms this was a purposive sample (Matthews \& Ross 2010; Sarantakos 2013). Six practitioners were interviewed and one of these interviews included a community garden visit. One non-government organisational (NGO) team was willing to participate as a group so this became a focus group of six. I used a semi-structured approach to the interviews, with the following questions.

- What interests you or concerns you about the environment in Taranaki?

- What do you notice about the environment (particularly the physical world) in relation to your clients/client group?

- How do you use the environment or your interest in the environment in your social work practice?

The interviews were qualitative, seeking rich data (Bryman 2008; Matthews \& Ross 2010; Sarantakos 2013; Tolich \& Davidson 2003) and from the data six themes emerged. In order to honour what was shared with me I kept participants engaged in the process by sharing material and re-getting consent each step of the process.

\section{Theoretical ideas}

The practice described fell loosely into two theoretical camps about environmental social work. One is what Besthorn (2011) and Zapf (2010) refer to as deep ecology. This is the rejection of divisions between human and nonhuman worlds, that is, we are from the earth not separate to it. This approach promotes harmony and connection between all living things. This is a challenge to what Coates (2004) describes as the false dichotomies of modernism, where we separate people from nature and he encourages a 'world view in which humans and the rest of nature are seen as interdependent and intimately connected' (p. 3). Practitioners using this approach acknowled ge and use the wisdom in the environment to benefit their clients (Payne 2005).

The other approach is rooted in critical theory which is based on a critique of capitalism and includes an analysis of the impact of capitalism on the environment (Briskman, Pease \& Allan 2009; Brookfield 2005; Dominelli 2012). Dominelli (2012) talks about this when she writes about 'green' social work. Social work from this perspective has an emphasis on the connection between environmental rights and social justice, an integration which Coates (2003: 9) also advocates for, saying that 'social work can play a central role in engaging people in the struggle for environmental and social justice'. 
Dominelli (2012) identifies poverty as an issue for 'green' social workers and says it is a disaster in its own right. It is noted by Coates (2003) and Dominelli (2012) that it is the poor who are most impacted by environmental damage. Dominelli (2012) states that globally poor people live in the most degraded environments and are, '... disproportionately subjected to industrial pollution and natural disasters' (p. 9).

Challenging the injustices that result from capitalism (Dominelli 2012) is crucial in addressing poverty and environmental damage. Capitalist systems or what Coates (2003: 8) calls a 'blind obsession with markets and profits' and our commitment to economic growth (Hamilton 2003) has contributed to our current environmental crisis (Brookfield 2005; Coates 2004; Dominelli 2012). Our, '...human search for fulfilment has been displaced by materialism, by an 'obsession with money and what it can buy" (Coates 2003: 8-9). Consumption has been our response to the pervasive nature of disconnection and has distracted us from the damage being done to the Earth (Coates 2003).

\section{Themes from the research}

Six overlapping themes were identified in the research:

- Disconnection from the environment.

- Use of the environment in order to build relationship.

- Connection of clients to the physical world to enhance healing.

- Gardening.

- Challenging the impact of capitalism.

- The difference between affluence and poverty.

Firstly, practitioners identified disconnection from the environment among their clients and noted they did not use the physical world as a source of food or recreation. Coates (2003) describes this as humans becoming, '...detached and alienated' (p. 8) from nature. In relation to client disconnection from the environment, one practitioner talked about it as a form of apathy:

They are completely disconnected from the environment .... the environment is supposed to rock on without them paying attention to it.

I was interested in the possibility that the environment could be a source of recreation or food. My experience as a social worker in the 1980s was that people would gather kai moana or hunt in order to make their income 'stretch'. This approach to coping with poverty appears to have changed over time, as there was no evidence that gathering food was a part of daily life. In relation to this, an NGO social worker said her clients, 'use what's in front of them but what's in front of them is a benefit'.

In relation to using the beach or bush for recreation, one participant said her client group doesn't use these options;

... as much as they potentially could...It's easier to stay home and turn on the tv, when you haven't got transport ... They don't use it as a source of entertainment or a source of food.

This raised the possibility of using the natural world as a tool of engagement, the second 
theme identified. One respondent who worked with young people talked about using the beach as an office:

I often go to the beach and just naturally take a rubbish bag and just role model - and I now have permission to take my dog, some of the kids are really hard to engage with.

This example illustrates using the beach as a neutral and relaxing place to have a conversation with a young person while simultaneously acting as a positive role model in the care of the environment. This is an example of Zapf's (2010) deep ecology whereby the young people connect to, and benefit from, the environment.

This practitioner is using the notion of 'place'; Zapf (2010) argues for the idea of 'place' and living well in 'place', describing the way a location and physical environment can have '...meaning, and emotional significance for people' (n.p.). This idea is also outlined by Maidment and Bay (2012) who state that central to our wellbeing are, '...notions of place, space, sustainability and identity' (p. 222).

A third theme identified is connecting clients to the physical world to enhance healing. In working with young people a worker said:

...sometimes young people who have tasks to complete get an opportunity to work with mentors spending significant time on the marae just purely learning about who they are ... sometimes mentors take them out eeling late at night and show them how they used to make in the olden days harakeke baskets to catch them.

There was also an example given of work with a long-term mental health service user working as the caretaker of a community garden and the healing he experienced from this. Coates (2003) considers nature has been underutilised in social work practice, but has potential for significant healing. The experience of this man and the young people in the above quote is one of regaining a sense of belonging (Coates, 2003) and reconnection with the natural world.

Gardening is a way of both addressing poverty through the production of healthy food and reconnecting people to the environment (Dewane 2011). Community gardens are not unique to Taranaki, but they were discussed extensively by respondents in this research and are the fourth theme identified. There are a number of examples of community gardens in Taranaki; in one community the garden was established specifically as a way to combat poverty. It is situated by a marae and has a community section as well as plots for whanau and local families; all of the plots must be organic. The food is used by the social worker as koha when she visits clients, as well as distributed to people in need and to supply the local foodbank (Cleaver, 2010). The garden has other uses; as a site for medicinal plants such as kawakawa and lavender and a place where young people can complete community work. This approach, of creating social change through a community initiative, is an example of ideas espoused by Dominelli (2012) in relation to 'green' social work and involves what Coates (2003: 113) calls the 're-establishment of a sense of community'.

Gardening was discussed by other practitioners and while they had used this approach themselves, either through community gardens or encouraging gardening by clients, they identified a number of issues. One was that community gardens may require more time 
than workers are able to devote to them; 'Initially I thought cool, gardening, because I like gardening, but I just don't have time'.

There were also issues discussed in relation to clients having gardens. For example, 'Some landlords won't allow gardens on small sections'.

A social worker used to supply food for clients from the community garden although noted this is not always appropriate.

Just because there's food I wouldn't necessarily take it to everyone. I had one family and there was genuine need so I took food and they were grateful ....And it doesn't replace the food bank at all, the foodbank would be the most valued practical option for clients.

A potential solution offered by one practitioner was offering fruit trees as they are sustainable and do not require ongoing care. Sustainability in social work is encouraged by Coates (2003), who says social workers should work towards a sustainable society.

Respondents in this study discussed the impact of consumerism on their client group, the fifth theme. While the wealthy are responsible for most of the world's consumption the malaise of (over) consumption spreads throughout society (Alston 2013; Coates 2003; Dominelli 2012; Hamilton 2003). Respondents in this research raised their frustration with the behaviour of the operators of ubiquitous 'clothing trucks' who 'ply their trade' in poor communities. One NGO social worker had this to say about the insidiousness of consumerism: 'It's easier to get a flat screen $\mathrm{tv}$ on hire purchase than it is to pay the power bill'.

The focus on social justice extends to environmental justice as capitalism impacts on both the human and nonhuman world (Brookfield 2005; Coates 2003; Dominelli 2012). Dominelli (2012) and Alston (2013) discuss the importance of the link between the wellbeing of people and their physical environment and the connecting of environmental rights and social justice. Coates (2003) also argues for poverty reduction, stating that this is a matter of equity and inclusion. Within this research the gap between rich and poor in our community was evident and discussed. This is particularly the case in Taranaki, as people who work in the oil and gas industry are very well paid.

The last theme in this research is the difference between affluent and poor clients. An NGO social worker said the following:

They are more likely to be concerned with green things ... they worry about it but don't do anything about it whereas poorer clients are worrying about themselves, they don't have the time to be worrying about anything else.

These differences, between those who have a reasonable standard of living and those who do not was discussed in the following two quotes.

The clients who I have who are quite wealthy and I've got clients from the oil industry, their issues are quite different to the issues that people in poorer areas experience, so their issues would typically be around the behaviour of children ... but kind of at the lower end of the spectrum of naughty ... when wealthier children are seen as a problem it's acted on. 
Wealthier parents are focused on, this is the problem, how do we fix it because everything else is ok ... In poor communities you get, this happened, this happened, this is going on and the kids are behaving terribly.

It was noted by practitioners working with families that, 'Single, mother-led families are the poorest and the most vulnerable ... and lonely women'.

It is noted that the difference between rural and urban was also evident in this project. Urban practitioners discussed having both affluent and poor clients, whereas poverty was discussed more by rural practitioners and inadequate housing was identified as a significant issue. One social worker referred to seeing more 'hungry kids' than she had in the past and described instances where baby formula was diluted due to poverty. Her response to this was to set up an automatic payment for the formula with a local supermarket to ensure the babies were fed adequately.

\section{Into the future}

During this project a social worker talked about 'green social work of the mind'. She was referring to the idea familiar to social work practitioners of, '....sowing the seed of change'. This change can be about how people live in 'place' (Zapf 2010), and how they think about and engage with the natural world. Gray, Coates and Hetherington (2013) argue for a paradigm shift in social work towards an:

...ecological consciousness [and social workers] break free of their academic silos and work in unison, or at least cooperatively, to better understand and respond to the many dimensions of climate change and environmental destruction (p. 2).

In considering the research question to what degree, and how, social workers in Taranaki connect their day-to-day practice to the natural environment, the reconnection with the natural world was evident. This means taking the environment part of the person in environment slogan literally, by reconnecting people to the physical world and using what Dominelli (2012) refers to as the 'largesse' (p. 6) of the environment. Clients can use nature for their betterment, for healing, recreation and food. This is living well in 'place' and Taranaki has a rich environment.

The practitioners in this study either talked directly about, or alluded to, the idea of ' going backward to go forward'. That is, using the bounty of the environment to live from in the way of our parents, grandparents and great grandparents. Fishing, hunting, gathering food, gardening and harvesting fruit are all ways of returning to past ways of living which don't involve consumerism and the accumulation of debt. While ideas of recycling are 'trendy' they are also sensible, and living within our means is wisdom from the past we could return to. Coates (2004) describes this as part of a process whereby social workers develop, '....a more holistic conception of human/Earth relationships [and] provides an alternative path for social work and all of humanity' (p. 6).

These things are ways of opting out to some extent of the capitalist system, of choosing to resist (Coates 2004). Jordan and Drakeford (2012) argue the faltering of capitalism is an opportunity for social workers to work towards, '....social justice and equality [and to focus on] better relationships as part of what is required for a sound approach to the environment' 
(p. 170). Besthorn (2013: 33) talks about the, '...profession's growing interest in linking social and environmental justice'. Making the link via justice includes stepping out of the professional 'silo' and forming alliances with environmental groups in order to work collaboratively for environmental and social justice (Coates 2003). Working jointly with others in Taranaki to hold oil companies and the dairy industry accountable for the impact of their business on the environment rather than being beholden to them for employment opportunities is a way of being a 'green' social worker.

My opinion, drawn from critical theory, is that poverty needs to be confronted and challenged, before or alongside other options. If you don't deal with poverty then other action will be undermined or fail. O'Brien (2013) refers to this, saying that working towards the elimination of poverty is a central task of social work if we are to take seriously our mandate of working for social justice. Dominelli (2012: 29) identifies, '...poverty is a key social disaster in its own right' and states it requires urgent attention. Coates (2003: 145) says it is crucial that the, '... poor and marginalised are given an effective political voice'. Social workers will be more effective if we collectively go back to our radical 'roots' and address the political as well as the personal, but go forward by incorporating postmodern ideas about fluidity and respect for diversity and difference (Fook 2002). 'Green' social work gives us a current lens drawing on critical theory so we can work with our clients to make the personal political (Dominelli 2012).

This research project is a limited exploration of social work and its connection to the environment based on one province. It is hoped this is a small and humble contribution to what will be a growing body of research and literature in Aotearoa. There is scope for regionally based research projects and larger-scale projects looking at environmental/'green' social work nationally.

It is evident that social workers in Taranaki are aware of working in ways which use the environment, the 'place', for the betterment of their clients. They are also cognisant of issues which affect their clients' everyday lives and show a desire to think about, and work for, political change in areas and among groups of clients where poverty is evident. Good social work practice is about the person and the environment and what Coates (2003) calls working for the common good; social workers in this study demonstrate this every day in their work.

\section{References}

Alston, M. (2013). Social work in the context of climate change and disasters. In M. Connolly \& L. Harms (Eds.). Social work: Contexts and practice (3rd edition). Melbourne: Oxford University Press.

Besthorn, F. (2011). Toward a deep-ecological social work: Its environmental, spiritual and political dimensions. Retrieved on the 25 October 2013 from: http:/ / www.ecosocialwork.org/index.php?option=com_content\&view=article\&id $=47 \&$ Itemid $=54$.

Besthorn, P. (2013). Radical equalitarian ecological justice. In M. Gray, J. Coates \& T. Hetherington (Eds.). Environmental Social Work. London/New York: Routledge.

Briskman, L., Pease, B. \& Allan, J. (2009). Introducing critical theories for social work in a neo-liberal context. In J. Allan, L. Briskman \& B. Pease (Eds.). Critical social work: Theories and practices for a socially just world (2nd ed.). Australia: Allen \& Unwin.

Brookfield, S. (2005). The power of critical theory for adult teaching and learning. England: Open University Press.

Bryman, A. (2008). Social research methods (3rd ed.). Oxford: Oxford University Press.

Cleaver, R. (2010). Community garden in the making. Stratford Press. Retrieved on 8 February 2013 from: http: / / www.stratfordpress.co.nz/news / community-garden-in-the-making/1017293/. 
Climate Justice Taranaki (2012). Fracking factsheet. Retrieved on 8 February 2012 from: http: / / climatejusticetaranaki. info/.

Coates, J. (2003). Ecology and social work: Toward a new paradigm. Halifax: Fernwood Publishing.

Coates, J. (2004). From ecology to spirituality and social justice. New Scholarship in the Human Services 3(1). Retrieved from: http: / / fsw.ucalgary.ca/currents_prod_v1/articles/coates_v3_n1.htm.

Coates, J. (2011). Social work and the environment: A progressive step forward. Retrieved on 25 October 2013 from: http: / / www.ecosocialwork.org / index.php?option=com_content\&view=article\&id=54\&Itemid=61.

Dewane, C. (2011). Environmentalism and social work: The ultimate social justice issue. Social Work Today 11(5): 20-23. Retrieved on 4 December 2013 from: http: / / www.socialworktoday.com/archive/092011p20.shtml.

Dominelli, L. (2012). Green social work: From environmental crisis to environmental justice. United Kingdom: Polity Press.

Fook, J. (2002). Social work: Critical theory and practice. London: Sage.

Gray, M., Coates, J., \& Hetherington, T. (2013). Introduction: Overview of the last ten years and typology of ESW. In M. Gray, J. Coates \& T. Hetherington (Eds.). Environmental social work. London/New York: Routledge.

Greenpeace New Zealand (2012). Dairy farming and climate change. Retrieved on the 7 February 2013 from: http: / / www.greenpeace.org/new-zealand/en/campaigns / climate-change/smart-farming/agriculture-and-climate-change/ dairy-and-climate-change/.

Hamilton, C. (2003). Growth fetish. Australia: Allen \& Unwin.

Hetherington, T. \& Boddy, J. (2013). Ecosocial work with marginalized populations: Time for action on climate change. In M. Gray, J. Coates \& T. Hetherington (Eds.). Environmental social work. London/New York: Routledge.

Intergovernmental panel on climate change (2007). Climate change 2007: Working group 2: Impacts, adaptation and vulnerability. Retrieved on 25 October 2013 from: http: / / www.ipcc.ch/publications_and_data/ar4/wg2/en/ ch11s11-2-2.html.

Intergovernmental Panel on Climate Change (2012). Managing the risks of extreme events and disasters to advance climate change adaptation. A special report of working groups I and II of the intergovernmental panel on climate change [C.B. Field, V. Barros, T.F. Stocker, D. Qin, D.J. Dokken, K.L. Ebi, M.D. Mastrandrea, K.J. Mach, G.-K. Plattner, S.K. Allen, M. Tignor, and P.M. Midgley (Eds.)]. Cambridge, UK, and New York, NY, USA: Cambridge University Press. Retrieved on 4 December 2013 from: http: / / www.ipcc.ch/publications_and_data/publications_and_data_reports.shtml.

International Bank for Reconstruction and Development/The World Bank (2012). Turn down the heat: Why a 4 degrees C warmer world must be avoided. Retrieved on 25 October 2013 from: http: / / www.worldbank.org.

International Federation of Social Workers (2013). Globalisation and the environment. Retrieved on the 25 October 2013 from http: / /ifsw.org/policies/globalisation-and-the-environment/.

International Federation of Social Workers, International Association of Schools of Social Work \& International Council on Social Welfare (2012). The global agenda for social work and social development: Commitment to action. Retrieved on 25 October 2013 from http: / / www.globalsocialagenda.org/.

Jordan, B. \& Drakeford, M. (2012). Social work and social policy under austerity. United Kingdom: Palgrave Macmillan.

Maidment, J. \& Bay, U. (2012). Rural practice: An agenda for the future. In J. Maidment \& U. Bay (Eds.). Social work in rural Australia: Enabling practice. Australia: Allen \& Unwin.

Matthews, B. \& Ross, L. (2010). Research methods: A practical guide for the social sciences. England: Pearson Education.

O’Brien, M. (2013). Social work, poverty and disadvantage. In M. Connolly \& L. Harms (Eds.). Social work: Contexts and practice (3rd edition). Melbourne: Oxford University Press.

Payne, M. (2005). Modern social work theory (3rd edition). Great Britain: Palgrave Macmillan.

Sarantakos, S. (2013). Social research (4th ed.). Great Britain: Palgrave Macmillan.

Tolich, M. \& Davidson, C. (2003). The fascinating world of social science research. In C. Davidson \& M. Tolich (Eds.). Social science research in New Zealand: Many paths to understanding (2nd ed.). Auckland: Pearson.

Venture Taranaki (2013). Oil and gas. Retrieved on 7 February 2013 from: http: / / www.taranaki.info/liveandwork/ contentplus.php/page/about-taranaki.

Waitangi Tribunal (1983). Report of the Waitangi Tribunal on the Motunui-Waitara claim. Wellington: Department of Justice. Retrieved on 4 December 2013 from: http:/ / www.waitangi-tribunal.govt.nz/ reports/summary. asp?reportid $=\{0 F F 26 C 03-F 956-40 F A-A D B 0-61 E A 0843 F 885\}$.

Zapf, M. (2006). Transforming social work's understanding of person and environment: Spirituality and the 'common ground'. Paper presentation for the First North American Conference of Spirituality and Social Work. University of Waterloo. Retrieved on 4 December 2013 from: http: / / anzasw.org.nz/documents / 0000/0000/ 0424/ Zapf_spirituality_and_social_work.pdf.

Zapf, M. (2010). Social work and the environment: Understanding people and place. Critical Social Work (11): 3. Retrieved on 4 December 2013 from: http://www1.uwindsor.ca/criticalsocialwork/social-work-and-theenvironment-understanding-people-and-place. 